[Review Paper]

\title{
High Potential of Interzeolite Conversion Method for Zeolite Synthesis
}

\author{
Tsuneji SANo*, Masaya ItAKURA, and Masahiro SADAKane \\ Dept. of Applied Chemistry, Graduate School of Engineering, Hiroshima University, \\ 1-4-1 Kagamiyama, Higashi-Hiroshima, Hiroshima 739-8527, JAPAN
}

(Received January 15, 2013)

\begin{abstract}
Many types of zeolites such as beta (hereinafter, ${ }^{*}$ BEA), CHA, LEV, RUT, and MFI were successfully synthesized by interzeolite conversion of FAU, *BEA, and LEV type zeolites as starting materials under various hydrothermal synthesis conditions. The crystallization rates of zeolites using such starting zeolites were notably elevated compared to rates observed in conventional hydrothermal syntheses using amorphous aluminosilicate gels. This characteristic enhancement in the crystallization rate results from the generation of locally ordered aluminosilicate species (nanoparts) through the decomposition/dissolution of the starting zeolite, resulting in assembly and evolution into another type of zeolite. The structural similarity between the starting zeolite and the final crystallized zeolite is a crucial factor for interzeolite conversion. These findings strongly indicate that the interzeolite conversion route is an attractive strategy for zeolite synthesis and zeolite design will be possible after methods to selectively assemble the nanoparts are established.
\end{abstract}

Keywords

Interzeolite conversion, Organic structure-directing agent, Composite building unit, Structural similarity, FAU type zeolite, Beta type zeolite

\section{Introduction}

Zeolites are a class of microporous crystalline aluminosilicates with a special type of pore system that are widely used in adsorption, catalysis, and ion-exchange applications. This diversity of applications is possible because of their unusual properties such as unique framework, high internal surface area, solid acidity, and molecular sieve and ion-exchange properties.

In general, medium-to-large pore size and high-silica zeolites are synthesized by hydrothermal treatment of amorphous aluminosilicate hydrogel as a starting material in the presence of various organic structure-directing agents (OSDAs). According to the International Zeolite Association (IZA), 206 framework types of zeolites have been registered until now ${ }^{1)}$. However, the OSDAs occlude the cages and pores in the final zeolite, and must be removed, generally by calcination at high temperatures, which generates harmful gaseous pollutants. Furthermore, the use of expensive OSDAs also increases the cost of the zeolite. Therefore, recent development toward OSDA-free zeolite synthesis using seed crystals has attracted considerable attention, and several research groups have succeeded in OSDA-free synthesis $\left.{ }^{2)} 11\right)$.

\footnotetext{
* To whom correspondence should be addressed.

* E-mail: tsano@hiroshima-u.ac.jp
}

In most zeolite syntheses, an amorphous phase is directly converted to a given type of zeolite, but the transformation is usually gradual and follows the sequence: amorphous phase $\rightarrow$ less stable zeolite $\rightarrow$ most stable zeolite. On this basis, several researchers have pointed out the high potential of another method for zeolite formation, based on the hydrothermal conversion of one zeolite type into another type (interzeolite con-

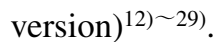

This study describes our recent investigations of the synthesis of several types of zeolites by interzeolite conversion of FAU (the three characters indicate the framework type code), beta (hereinafter, ${ }^{*}$ BEA), and LEV type zeolites in the presence and absence of $\operatorname{OSDAs}^{30) \sim 44)}$, and reviews the potential of interzeolite conversion as an alternative method for zeolite synthesis.

\section{Interzeolite Conversion in the Presence of OSDA}

\section{1. Effects of Hydrothermal Synthesis Conditions} Hydrothermal conversion of FAU type zeolite into *BEA type zeolite was carried out in the presence of tetraethylammonium hydroxide (TEAOH), a typical OSDA for the synthesis of *BEA type zeolite, which is one of the most industrially important zeolites. Figure 1 shows that the use of FAU type zeolite as a starting material achieved enhanced crystallization rate 
compared to amorphous aluminosilicate hydrogel prepared from fumed silica and $\gamma$-alumina ${ }^{30)}$. Such enhancement in the crystallization rate of *BEA type zeolite is due to the locally ordered aluminosilicate species (nanoparts) formed by decomposition/dissolution of FAU type zeolite. Nanopart assembly in the presence of a specific OSDA results in rapid crystallization and high selectivity for a particular zeolite. These results led us to the hypothesis that the structure of the nanoparts can be modified by changing the OSDA, which is also used as an alkali source for decomposition of zeolite. Therefore, the hydrothermal conversion of FAU type zeolite was carried out with various OSDAs (Table 1).

Use of tetramethylammonium hydroxide (TMAOH), benzyltrimethylammonium hydroxide (BTMAOH), and choline hydroxide (Choline) resulted in the formation of highly crystalline and pure RUT, CHA, and LEV type zeolites, respectively ${ }^{31), 32), 34)}$. The framework structures of these zeolites are shown in Table 2. High-silica CHA type zeolites, SSZ-13, are generally

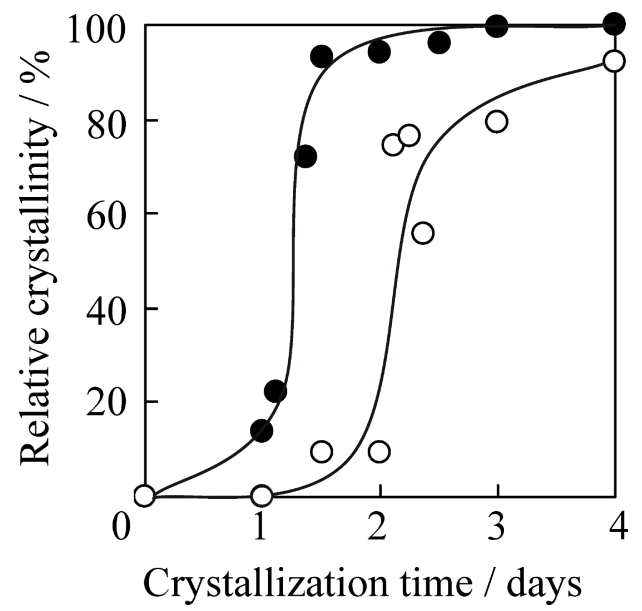

Fig. 1 Crystallization Curves of *BEA Type Zeolites from FAU Type Zeolite and $(O) \mathrm{SiO}_{2} / \gamma-\mathrm{Al}_{2} \mathrm{O}_{3}$ in the Presence of TEAOH synthesized from amorphous aluminosilicate hydrogels in the presence of expensive $N, N, N$-trimethyladamantammonium cation (TMAda ${ }^{+}$), but we found that BTMAOH is an alternative OSDA to TMAda ${ }^{+}$. On the other hand, higher synthesis temperature yielded MTN type zeolite ${ }^{35)}$. Further addition of $\mathrm{NaOH}$ yielded high-silica OFF type zeolite with no or very little ERI type zeolite ${ }^{36)}$. The framework structures of OFF and ERI are closely related, so stacking faults or intergrowth of these two zeolites are well known to be very common.

RUT type zeolite was also obtained from *BEA type zeolite in the presence of TMAOH ${ }^{41)}$. The crystallization curves from both FAU and *BEA type zeolites with a Si/Al ratio of 77 are presented in Fig. 2. Crystallization from *BEA type zeolite was achieved within 7 days, whereas prolonged crystallization time was needed for FAU type zeolite. Taking into account the fact that an induction period was observed for FAURUT interzeolite conversion, we suggest that the crystallization rate of RUT type zeolite from * BEA type zeolite is faster than that from FAU type zeolite. These results strongly indicate that the structure and concentration of nanoparts formed by decomposition/dissolution of starting zeolite are modified by the framework structure of the starting zeolite.

\section{2. Addition of Seed Crystals to FAU-* BEA Interzeolite Conversion}

In general, adding seed crystals of the desired zeolite phase to the starting synthesis gel is well recognized to enhance the crystallization rate. Moreover, this metod can also control the crystal size distribution. Although the mechanism of crystallization rate enhancement has not been clarified, two explanations have been offered: increased surface area due to the addition of seed crystals results in increased and faster consumption of reagents, or seed crystals promote nucleation through some secondary nucleation mechanism ${ }^{45)} \sim 48$ ).

Figure 3 shows the X-ray diffraction (XRD) patterns of the products obtained at various crystallization times

Table 1 Zeolites Obtained by Interzeolite Conversion of FAU Type Zeolites Using Several OSDAs

\begin{tabular}{|c|c|c|c|c|c|}
\hline \multirow{2}{*}{ OSDA } & \multirow{2}{*}{ Seed } & \multirow{2}{*}{ Temp. $\left[{ }^{\circ} \mathrm{C}\right]$} & \multicolumn{2}{|r|}{ Zeolite } & \multirow{2}{*}{ Ref. } \\
\hline & & & Framework type code & Channels & \\
\hline ТМАOH & & 140 & RUT & apertures formed by 6-rings only & 31) \\
\hline TEAOH & & 140 & *BEA & $126.6 \times 6.7 \AA$ & 30) \\
\hline ВТМАОН & & 170 & MTN & apertures formed by 6-rings only & $35)$ \\
\hline ВТМАOH & & 125 & CHA & $83.8 \times 3.8 \AA$ & 32) \\
\hline BTMAOH $(+\mathrm{NaOH})$ & & 125 & OFF & $126.7 \times 6.8 \AA$ & 36) \\
\hline Choline & & 125 & LEV & $83.6 \times 4.8 \AA$ & 34) \\
\hline TMAOH & *BEA & 125 & FAU, Am. ${ }^{\text {a) }}$ & & 38) \\
\hline Choline & *BEA & 125 & *BEA, Un. ${ }^{\text {b) }}$ & & 38) \\
\hline ВТМАОН & $*$ BEA & 125 & *BEA & $126.6 \times 6.7 \AA$ & 38) \\
\hline$(\mathrm{NaOH})$ & *BEA & 125 & *BEA & $126.6 \times 6.7 \AA$ & 38) \\
\hline
\end{tabular}

a) Am: amorphous phase. b) Un: unknown phase. 
Table 2 Framework Structures and Composite Building Units of Various Zeolites

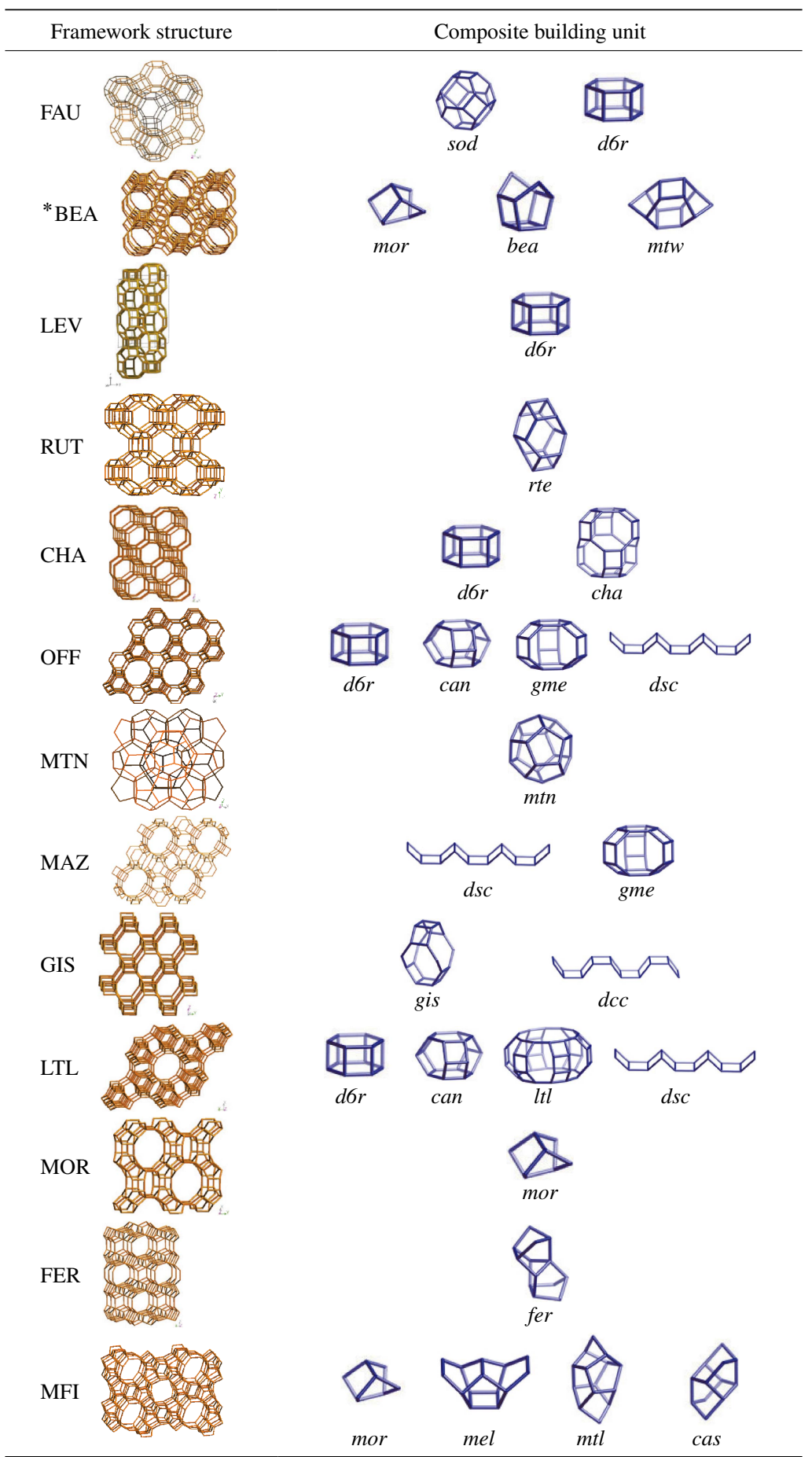

in the absence and presence of ${ }^{*}$ BEA seed crystals ${ }^{38)}$. Considerable differences were observed in the decomposition/dissolution behavior of the starting FAU type zeolite. In the absence of seed crystals, the diffraction peaks corresponding to FAU type zeolite were clearly observed even after hydrothermal treatment for $2 \mathrm{~h}$, but these peaks disappeared completely after $1 \mathrm{~d}$, whereas strong diffraction peaks assigned to *BEA type zeolite were clearly observed after hydrothermal treatment for
$3 \mathrm{~d}$. On the other hand, in the presence of seed crystals, the diffraction peaks of FAU type zeolite disappeared completely after hydrothermal treatment for $2 \mathrm{~h}$. Surprisingly, the diffraction peaks corresponding to *BEA type zeolite was clearly observed after $2 \mathrm{~h}$, and peak intensities hardly changed with longer hydrothermal treatment time, indicating that the crystallization rate of *BEA type zeolite was extremely high. Furthermore, the enhancement in the crystallization rate 


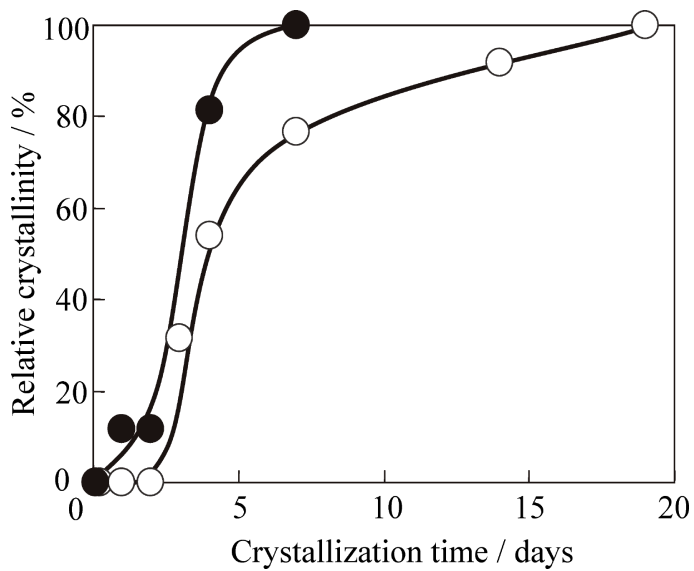

Fig. 2 Crystallization Curves of RUT Type Zeolites Obtained from (O) *BEA and $(\bigcirc)$ FAU Type Zeolites
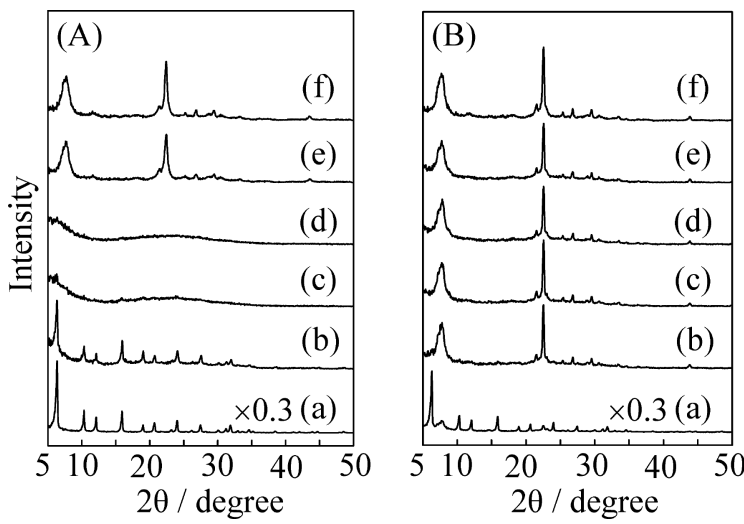

(a) $0 \mathrm{~h}$, (b) $2 \mathrm{~h}$, (c) $1 \mathrm{~d}$, (d) $2 \mathrm{~d}$, (e) $3 \mathrm{~d}$, and (f) $7 \mathrm{~d}$.

Fig. 3 XRD Patterns of the Products Obtained from FAU Type Zeolite in the (A) Absence and (B) Presence of Seed Crystals at Various Crystallization Times

strongly suggests that the rate of incorporation of nanoparts formed by the decomposition/dissolution of FAU type zeolite onto seed crystal surfaces or nuclei was enhanced; consequently, the decomposition/dissolution rate of FAU type zeolite increased.

These findings strongly suggest that the nanoparts formed in the presence of OSDAs other than TEAOH also contribute to the crystallization of *BEA type zeolite if their chemical structures are suitable for seedassisted crystal growth. Therefore, we investigated the effects of OSDAs other than TEAOH on FAU- * BEA interzeolite conversion (Table 1). Interzeolite conversion of FAU type zeolite was performed in the presence of *BEA seed crystals by adding various OSDAs such as TMAOH, BTMAOH, and Choline instead of TEAOH, which had already been found to be effective for the synthesis of RUT, CHA, and LEV type zeolites, respectively, from FAU type zeolite. As expected, when BTMAOH was used, highly crystalline and pure
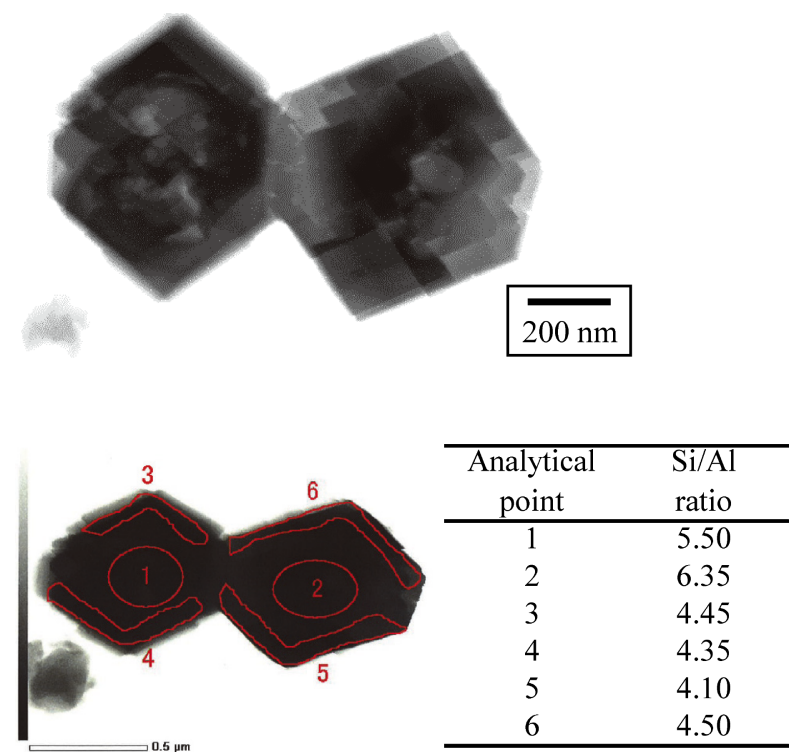

Fig. 4 TEM/EDX Analysis of LEV Type Zeolite Crystals Obtained from FAU Type Zeolite

*BEA type zeolite was obtained. Moreover, OSDAfree interzeolite conversion of FAU into *BEA type zeolite was achieved by seeding ${ }^{38)}$.

\section{Seed-assisted OSDA-free Interzeolite Conversion}

\section{1. FAU-LEV Interzeolite Conversion}

All the above results strongly suggest that desired zeolites can be synthesized using seed crystals in the absence of OSDA if the starting FAU type zeolite is decomposed/dissolved into nanoparts with chemical structures suitable for crystallization into the desired zeolite. Therefore, we applied the interzeolite conversion method to the OSDA-free zeolite synthesis.

Figure 4 displays typical results of transmission electron microscope/energy dispersive X-ray fluorescence spectrometer (TEM/EDX) analysis of the LEV type zeolite crystals obtained from the OSDA-free conversion of FAU type zeolite in the presence of noncalcined LEV seed crystals with a $\mathrm{Si} / \mathrm{Al}$ ratio of 10.7 $\left(\right.$ Table 3) ${ }^{39)}$. The TEM image shows the presence of smaller crystals within the larger crystals of LEV type zeolite, indicating that this LEV type zeolite possesses a peculiar core/shell structure. The smaller crystals are possibly partially decomposed/dissolved seed crystals. The EDX analysis revealed that the $\mathrm{Si} / \mathrm{Al}$ ratio of the shell (4.1-4.4) was lower than that of the core (5.56.4), indicating a thin Al-rich shell is wrapped around the core. The Al-rich shell is considered to be formed from the Al-rich aluminosilicate species produced by the decomposition/dissolution of the starting FAU type zeolite under highly alkaline conditions. The Si/Al ratio of the core was lower than that of the seed crystals, 
Table 3 Hydrothermal Conversion of FAU Type Zeolite and Products Obtained ${ }^{\mathrm{a}}$

\begin{tabular}{|c|c|c|c|c|c|c|c|c|}
\hline $\begin{array}{c}\text { Sample } \\
\text { No. }\end{array}$ & $\begin{array}{c}\text { Starting } \\
\text { materials }\end{array}$ & $\begin{array}{l}\mathrm{Si} / \mathrm{Al} \\
\text { ratio }\end{array}$ & $\mathrm{MOH} / \mathrm{SiO}_{2}$ & $\begin{array}{c}\text { Seed } \\
{[\mathrm{wt} \%]}\end{array}$ & $\begin{array}{l}\text { Time } \\
\text { [days] }\end{array}$ & $\begin{array}{l}\text { Temp. } \\
{\left[{ }^{\circ} \mathrm{C}\right]}\end{array}$ & Products & $\begin{array}{c}\text { Yield } \\
{[\%]}\end{array}$ \\
\hline 1 & FAU & 19 & $0.6(\mathrm{NaOH})$ & $\operatorname{LEV}(16.7)^{\mathrm{b})}$ & 3 & 125 & LEV & 26 \\
\hline 2 & FAU & 26 & $0.6(\mathrm{NaOH})$ & $\operatorname{LEV}(16.7)^{\mathrm{c})}$ & 3 & 125 & Am. ${ }^{\mathrm{d})}$ & \\
\hline 3 & FAU & 17 & $0.6(\mathrm{NaOH})$ & $\operatorname{MAZ}(33.3)^{\mathrm{b})}$ & 14 & 70 & MAZ & 34 \\
\hline 4 & FAU & 25 & $0.6(\mathrm{NaOH})$ & & 7 & 125 & GIS & 15 \\
\hline 5 & $\mathrm{Cab}-\mathrm{O}-\mathrm{Sil} \mathrm{M} 5 / \mathrm{NaAlO}_{2}$ & 26 & $0.6(\mathrm{NaOH})$ & & 7 & 125 & Am. ${ }^{\mathrm{d})}$ & \\
\hline 6 & FAU & 25 & $0.6(\mathrm{KOH})$ & & 7 & 125 & LTL & 18 \\
\hline 7 & $\mathrm{Cab}-\mathrm{O}-\mathrm{Sil} \mathrm{M} 5 / \mathrm{NaAlO}_{2}$ & 26 & $0.6(\mathrm{KOH})$ & & 7 & 125 & Am. ${ }^{\text {d) }}$ & \\
\hline 8 & FAU & 76 & $0.6(\mathrm{NaOH})$ & & 7 & 125 & MOR & 26 \\
\hline 9 & FAU & 25 & $0.6(\mathrm{NaOH})$ & & 7 & 140 & MOR, GIS & \\
\hline 10 & $\mathrm{Cab}-\mathrm{O}-\mathrm{Sil} \mathrm{M} 5 / \mathrm{NaAlO}_{2}$ & 25 & $0.6(\mathrm{NaOH})$ & & 7 & 140 & MOR, GIS & \\
\hline 11 & FAU & 25 & $0.6(\mathrm{NaOH})$ & FER (9.1) & 1 & 150 & FER & 30 \\
\hline 12 & $\mathrm{Cab}-\mathrm{O}-\mathrm{Sil} \mathrm{M} 5 / \mathrm{NaAlO}_{2}$ & 25 & $0.6(\mathrm{NaOH})$ & FER (9.1) & 1 & 150 & FER & 18 \\
\hline 13 & FAU & 25 & $0.6(\mathrm{NaOH})$ & FER (9.1) & 1 & 125 & GIS & 19 \\
\hline 14 & $\mathrm{Cab}-\mathrm{O}-\mathrm{Sil} \mathrm{M} 5 / \mathrm{NaAlO}_{2}$ & 25 & $0.6(\mathrm{NaOH})$ & FER (9.1) & 1 & 125 & FER & 20 \\
\hline
\end{tabular}

a) $\mathrm{H}_{2} \mathrm{O} / \mathrm{SiO}_{2}=15$. b) non-calcined seed crystal. c) calcined seed crystal. d) Am.: amorphous phase.

indicating that dissolution of seed crystals also partially occurred during the conversion process.

Pure LEV type zeolite was reproducibly obtained only in the presence of non-calcined seed crystals, so the presence of the choline cation in the zeolitic pores of the seed crystals in the conversion process may be important. The crystallization rate of a zeolite can be increased by adding seed crystals and such rate increase is due to a higher surface area and/or promotion of nucleation through some secondary nucleation mechanism, suggesting that the hydrothermal stability of seed crystals is very important. Therefore, the hydrothermal stability of the seed crystals was investigated by comparison of the XRD pattern of the product obtained from conversion of FAU type zeolite in the presence of non-calcined seed crystals (after hydrothermal treatment time of only $30 \mathrm{~min}$ ) with the XRD pattern of the product obtained using calcined seed crystals. In the product formed with non-calcined seed crystals, diffraction peaks typical of the LEV phase were clearly observed, whereas the peaks due to the FAU phase disappeared completely. In contrast, in the product using the calcined seed crystals, no distinctive peaks were observed (Table 3). These results demonstrate that the choline cation-containing LEV seed crystals are more stable than the calcined crystals and consequently, the crystal surfaces of the non-calcined seed crystals contribute to the crystal growth of LEV type zeolite ${ }^{39}$.

Based on these results, we also achieved OSDA-free FAU to MAZ interzeolite conversions in the presence of non-calcined MAZ seed crystals with a Si/Al ratio of $3.88(\text { Table } 3)^{40)}$. Table 2 lists the framework structures and composite building units of several zeolites as summarized in the database of the Structure Commission of IZA ${ }^{1)}$. Recently, common composite building units between the seed zeolite and the finally crystallized zeolite from the seed-free starting gel were proposed to be the crucial precursors for crystal growth in the seed-assisted OSDA-free zeolite synthesis ${ }^{49)}$. The starting FAU type zeolite contains the composite building units sod and $d 6 r$, the final LEV type zeolite contains $d 6 r$ (the common building unit with FAU type zeolite), *BEA type zeolite contains mor, bea, and $m t w$, and MAZ type zeolite contains the $d s c$ and gme units. Although FAU and *BEA or FAU and MAZ seem to have no common composite building unit, a common four-membered ring (4 MR) chain is observed in the composite building units of $d 6 r$, bea, $d s c$, and gme, which may act as the common building unit. These results strongly suggest that the structural similarity between the starting zeolite (FAU) and the final crystallized zeolite ( ${ }^{*} \mathrm{BEA}, \mathrm{LEV}$, and MAZ) is the crucial factor for zeolite crystal growth. To further understand the interzeolite conversion process, we examined the interzeolite conversion of FAU and *BEA type zeolites in the absence of OSDA under various hydrothermal conditions.

\section{2. OSDA-free Interzeolite Conversion of FAU and ${ }^{*} B E A$ Type Zeolites under Various Hydrothermal Conditions \\ Interzeolite conversion of FAU type zeolites was con-} ducted using only alkaline metal hydroxides in the absence of seed crystals (Table 3) ${ }^{44}$. Using $\mathrm{NaOH}$ as both the alkali source and the inorganic SDA, GIS type zeolite was obtained from FAU type zeolite, whereas using $\mathrm{KOH}$, LTL type zeolite was obtained. For comparison, zeolite synthesis was carried out via conventional hydrothermal synthesis using amorphous materials of fumed silica (Cab-O-Sil M5) and $\mathrm{NaAlO}_{2}$ as the initial $\mathrm{Si}$ and $\mathrm{Al}$ sources, but no zeolite phase was obtained. GIS type zeolite contains the composite building units $d c c$ and gis, whereas LTL type zeolite contains $d 6 r$, can, $l t l$, and $d s c$ units (Table 2). Except for the $d 6 r$ unit in LTL type zeolite, there is no overlap 
Table 4 Hydrothermal Conversion of *BEA Type Zeolite ${ }^{\text {a) }}$

\begin{tabular}{cccccc}
\hline $\begin{array}{c}\text { Sample } \\
\text { No. }\end{array}$ & $\begin{array}{c}\text { Seed } \\
{[\mathrm{wt} \%]}\end{array}$ & $\begin{array}{c}\text { Temp. } \\
{\left[{ }^{\circ} \mathrm{C}\right]}\end{array}$ & $\begin{array}{c}\text { Time } \\
{[\text { days] }}\end{array}$ & Products & $\begin{array}{c}\text { Yield } \\
{[\%]}\end{array}$ \\
\hline 15 & - & 125 & 7 & *BEA, MOR & \\
16 & LEV $(16.7)$ & 125 & 3 & LEV, MOR & \\
17 & - & 70 & 14 & Am. $)$ & \\
18 & MAZ $(33.3)$ & 70 & 14 & MAZ & 18 \\
19 & FER $(9.1)$ & 125 & 1 & FER & 20 \\
\hline
\end{tabular}

a) $\mathrm{Si} / \mathrm{Al}=21, \mathrm{NaOH} / \mathrm{SiO}_{2}=0.6, \mathrm{H}_{2} \mathrm{O} / \mathrm{SiO}_{2}=15$.

b) Am.: amorphous phase.

of composite building unit between the starting and product zeolites, suggesting that interzeolite conversion would not occur. However, a $4 \mathrm{MR}$ chain is present in all these composite building units that serves as the common element, suggesting that nanoparts formed from the starting FAU type zeolite in the presence of $\mathrm{Na}^{+}$and $\mathrm{K}^{+}$cations are similar to the GIS and LTL type zeolite precursors, respectively.

MOR type zeolite was obtaind instead of GIS and LTL type zeolites in the interzeolite conversion of FAU type zeolite with higher $\mathrm{Si} / \mathrm{Al}$ ratios. MOR type zeolite was also formed at higher temperature. The initial amorphous gel prepared from Cab-O-Sil M5 and $\mathrm{NaAlO}_{2}$ also gave MOR type zeolite, and FAU and MOR type zeolites have no common composite building unit, suggesting that the structures of the nanoparts produced from FAU type zeolite with high $\mathrm{Si} / \mathrm{Al}$ ratios or under high-temperatures could be similar to those of aluminosilicate species derived from amorphous aluminosilicate gel. However, extensive decomposition of the staring FAU type zeolite must occur.

To further confirm the importance of this structural similarity, hydrothermal conversion of FAU type zeolite was carried out in the presence of FER seed crystals with a Si/Al ratio of 25 (Table 3$)^{44)}$. FAU and FER type zeolites have no structural similarities (Table 2). FAU-FER interzeolite conversion occurred at $150{ }^{\circ} \mathrm{C}$. However, pure GIS type zeolite was obtained even in the presence of FER seed crystals at $125^{\circ} \mathrm{C}$. In contrast, FER type zeolite was obtained from amorphous materials regardless of synthesis temperature. These results indicate that the structure of the nanoparts produced by decomposition/dissolution of FAU type zeolite is strongly dependent on the synthesis conditions such as Si/Al ratio and temperature. Under mild hydrothermal condition $\left(125^{\circ} \mathrm{C}\right)$, nanoparts with a $4 \mathrm{MR}$ chain structure are produced from the starting FAU type zeolite, resulting in the formation of GIS type zeolite through the assembly of these nanoparts. However, at higher temperature $\left(150{ }^{\circ} \mathrm{C}\right)$, FAU type zeolite decomposes to yield aluminosilicate species similar to those formed from amorphous starting materials. The structure of the aluminosilicate species is rather similar to that of the $5 \mathrm{MR}$-containing precursor of FER type zeo- lite, so is probably incorporated into the FER seed crystals.

*BEA type zeolite contains the composite building units of mor, bea, and $m t w$, which are formed of $4 \mathrm{MR}$ and $5 \mathrm{MR}$. Therefore, the transformation behavior of *BEA type zeolite is likely to be different to that of FAU type zeolite. We investigated the transformation behavior of *BEA type zeolite in the absence of OSDA under various synthesis conditions ${ }^{44)}$. As indicated in Table 4, although *BEA type zeolite did not decompose completely even after 7 days, MOR type zeolite phase was observed, suggesting that the starting *BEA type zeolite is stable under these hydrothermal synthesis conditions, and that the formation of MOR type zeolite is due to the common composite building unit mor.

As described above, the OSDA-free synthesis of LEV and MAZ type zeolites can be achieved by hydrothermal conversion of FAU type zeolite in the presence of seed crystals ${ }^{39), 40)}$. Based on this finding, we investigated the effect of adding seed crystals on the OSDAfree interzeolite conversion of *BEA type zeolite ${ }^{44)}$. The addition of LEV seed crystals led to the formation of LEV type zeolite. However, MOR type zeolite was also present in the product. Conversely, addition of MAZ seed crystals led to the formation of pure MAZ type zeolite, although the yield was lower than that obtained by interzeolite conversion of FAU type zeolite. FAU, LEV, and MAZ type zeolites contain composite building units formed mainly of $4 \mathrm{MR}$, whereas *BEA and MOR type zeolites contain composite building units formed of $4 \mathrm{MR}$ and $5 \mathrm{MR}$. Decomposition of FAU type zeolite apparently yields many $4 \mathrm{MR}$ containing composite building units compared to decomposition of *BEA type zeolite. Therefore, the difference in the yield of MAZ type zeolite in seen in interzeolite conversion starting with FAU and *BEA type zeolites is due to the difference in the amount of available 4 MR-based building units.

If our hypothesis is correct, ${ }^{*}$ BEA type zeolite is suitable for the synthesis of zeolites containing only 5 MR-based composite building units. To confirm this prediction, hydrothermal conversion of *BEA type zeolite was carried out in the presence of FER seed crystals, which contain the fer composite building unit 


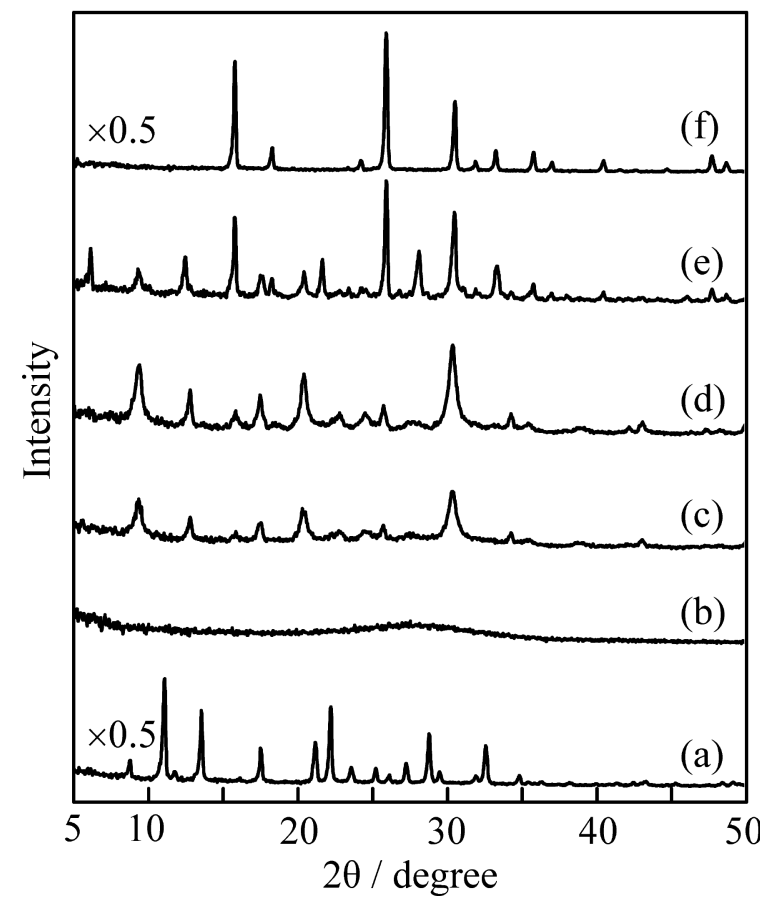

(a) Starting LEV and (b-f) products at (b) $0.5 \mathrm{~h}$, (c) $1 \mathrm{~h}$, (d) $1.5 \mathrm{~h}$, (e) $8 \mathrm{~h}$, and (f) $24 \mathrm{~h}$.

Fig. 5 XRD Patterns of Products Obtained from LEV Type Zeolite at Various Crystallization Times

formed of only $5 \mathrm{MR}^{44)}$. As expected, pure FER type zeolite was obtained. From these results, we concluded that the structures of nanoparts could be altered through the choice of starting zeolite, indicating that zeolite synthesis can be controlled by selective assembly of building units with specific structures.

\section{Seed and OSDA-free Interzeolite Conversion}

\section{1. Transformation of LEV into CHA}

To confirm the validity of our hypothesis that structural similarity between the starting zeolite and the final crystallized zeolite is the crucial factor for zeolite crystal growth, we investigated the LEV-CHA transformation in the absence of both OSDA and seed crystals. As can be seen in Table 2, these zeolites have similar composite building units. Figure 5 shows the XRD patterns of the products obtained at various hydrothermal treatment times ${ }^{42)}$. The findings clearly show that the starting LEV type zeolite decomposed into an amorphous phase, and then the pure CHA type zeolite crystallized after $1.5 \mathrm{~h}$ of hydrothermal treatment. At longer treatment times, the peaks corresponding to the CHA phase decreased, and peaks corresponding to the GIS and ANA phases together with a small amount of FAU phase were observed after $8 \mathrm{~h}$ of hydrothermal treatment. Finally, pure ANA type zeolite was obtained after $24 \mathrm{~h}$. Therefore, a transformation se-
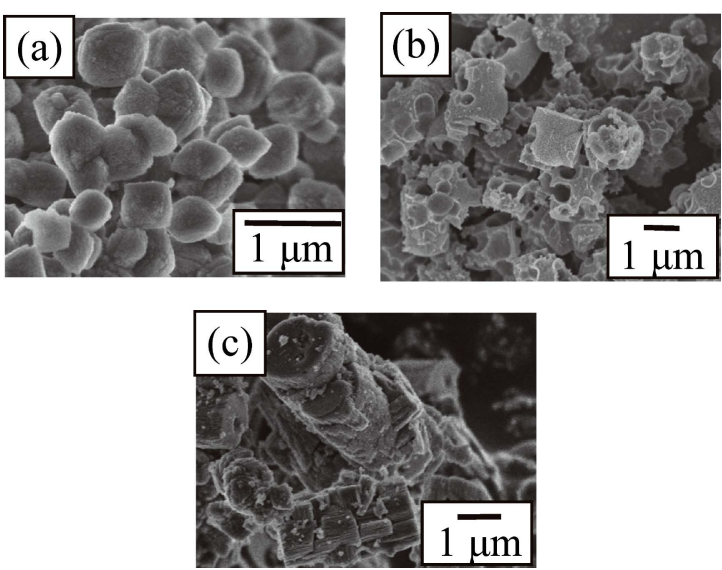

Fig. 6 SEM Images of (a) Starting *BEA and MFI Type Zeolites Obtained at Synthesis Times of (b) $30 \mathrm{~min}$ and (c) $24 \mathrm{~h}$

quence from LEV $\rightarrow$ an amorphous phase $\rightarrow$ CHA $\rightarrow$ ANA was observed. Although the GIS, ANA, and FAU type zeolites were formed from amorphous aluminosilicate hydrogel prepared using $\mathrm{Cab}-\mathrm{O}-\mathrm{Sil} \mathrm{M} 5$ and $\mathrm{NaAlO}_{2}$, no formation of CHA type zeolite was observed, which indicates that the transformation of LEV type zeolite to metastable CHA type zeolite is a kinetically controlled process, whereas the transformation to the most stable ANA type zeolite is a thermodynamically controlled process. To the best of our knowledge, this is the first report on the transformation of LEV type zeolite into less dense CHA type zeolite.

\section{2. *BEA-MFI Interzeolite Conversion}

MFI type zeolite contains the composite building units cas, mel, $m f i$, and mor consisting of $4 \mathrm{MR}$ and $5 \mathrm{MR}$, indicating that the mor unit is the common building unit between *BEA and MFI type zeolites. On this basis, we attempted to synthesize MFI type zeolite by interzeolite conversion of *BEA type zeolite in the absence of both OSDA and seed crystals ${ }^{44)}$. As expected, *BEA-MFI interzeolite conversion was observed using * BEA type zeolites with high $\mathrm{Si} / \mathrm{Al}$ ratios as the starting material. Moreover, MFI type zeolite was not obtained using FAU type zeolite or amorphous aluminosilicate gel as the starting materials. These results imply that nanoparts produced by the dissolution/ decomposition of *BEA type zeolites are involved in the nucleation and crystal growth of MFI type zeolite.

As shown in Fig. 6, the outer surfaces of the MFI crystals obtained were very rough, and a large number of macropores were observed. However, the surface became smoother with longer hydrothermal treatment time. Figure 7(A) shows the $\mathrm{N}_{2}$ adsorption-desorption isotherms of MFI type zeolites at various reaction times. A clear hysteresis loop was observed for MFI type zeolite obtained after $6 \mathrm{~h}$, but at longer reaction times (12 and $24 \mathrm{~h}$ ), the hysteresis loop became less pronounced, and the BET specific surface areas $(6 \mathrm{~h}$ : 

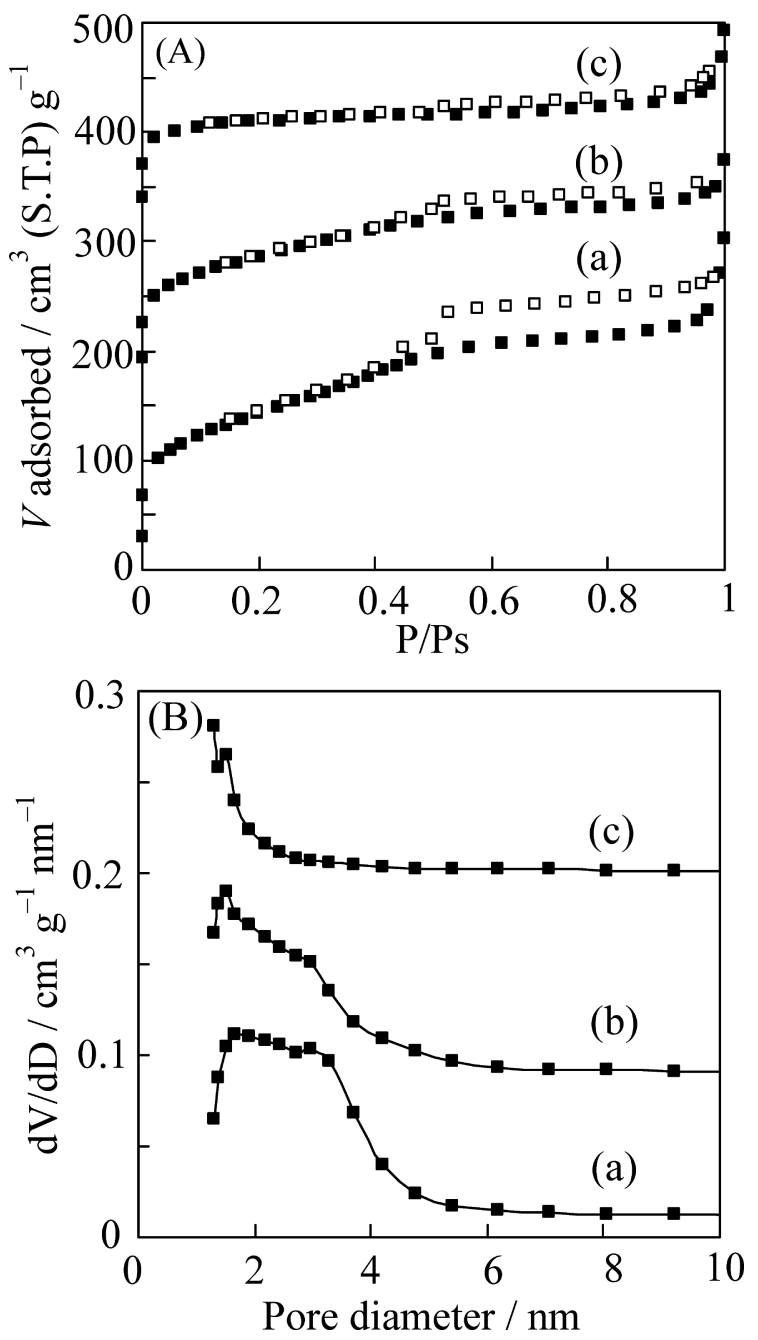

Fig. 7 (A) $\mathrm{N}_{2}$ Adsorption-desorption Isotherms and (B) BJH Pore Size Distributions of MFI Type Zeolites Obtained at Synthesis Times of (a) 6 h, (b) 12 h, and (c) $24 \mathrm{~h}$

510, $12 \mathrm{~h}: 480$, and $24 \mathrm{~h}: 370 \mathrm{~m}^{2} \mathrm{~g}^{-1}$ ) and pore volumes (6 h: 0.31, 12 h: 0.27, and $24 \mathrm{~h}: 0.17 \mathrm{~cm}^{3} \mathrm{~g}^{-1}$ ) decreased. Mesopore size analysis by the BJH method yielded broad peaks of 2 to $4 \mathrm{~nm}$ (Fig. 7(B)). The number of mesopores decreased with increasing synthesis time, indicating the elimination of mesopores by crystal growth of the MFI type zeolite. Although we do not have enough data to explain the exact formation mechanism of mesopores at the present time, we speculate that $*$ BEA type zeolite crystals are relatively stable under the present interzeolite conversion conditions and yield slightly large nanoparts as compared to FAU type zeolite crystals, so assembly results in formation of mesopores within MFI type zeolite crystals.

Based on the above results, we concluded that mesoporous MFI type zeolites can be readily synthesized from * BEA type zeolites by the interzeolite conversion method. The formation of mesoporous zeolites has been actively sought as a way to overcome the diffusion

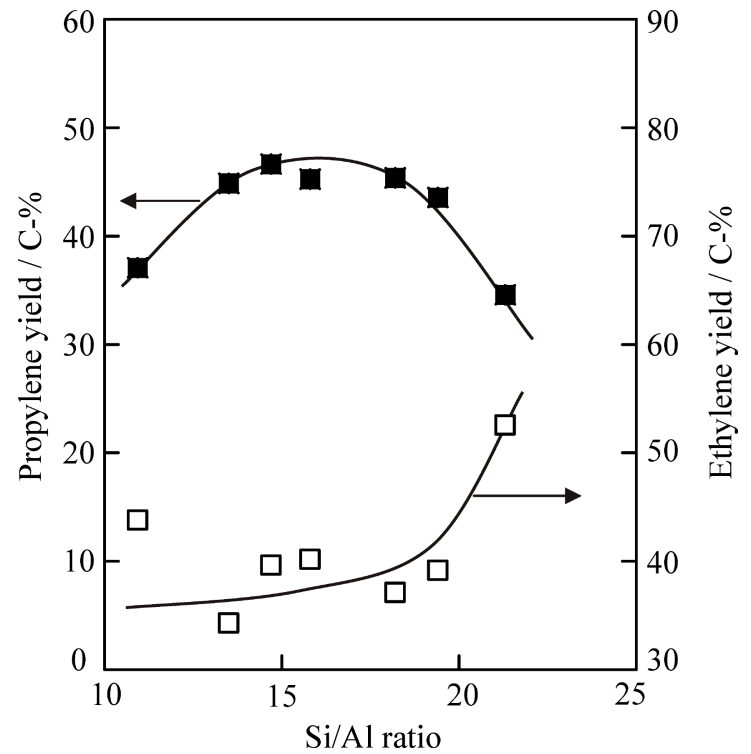

Reaction conditions: EtOH/ $\mathrm{N}_{2}=50 / 50$ vol\%, temp. $=400{ }^{\circ} \mathrm{C}, W / F=$

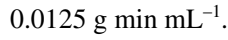

Fig. 8 Relationship between Si/Al Ratio of CHA Type Zeolite and Yield of Light Olefins $((\square)$ ethylene and $(\square)$ propylene)

limitation of reagents and products. There are several approaches for synthesizing mesoporous zeolites, such as the use of carbon particles as hard templates ${ }^{50)}$, the use of organosilane surfactants as soft templates ${ }^{51)}$, and, more recently, the desilication method ${ }^{52)}$. Therefore, the interzeolite conversion method provides a new route for creating mesopores in zeolites, although the need for two steps (synthesis of starting zeolite and hydrothermal conversion) and the lower product yield presents major problems.

\section{Synthesis and Applications of High-silica CHA Type Zeolite from FAU Type Zeolite}

\section{1. Catalyst for Ethanol to Olefin Reactions}

CHA type zeolites with a wide range of $\mathrm{Si} / \mathrm{Al}$ ratios (13.4-21.5) were obtained with shorter crystallization time by adding seed crystals in the presence of BTMAOH. Catalytic performance for ethanol conversion to light olefins was evaluated. Figure 8 shows the relationship between the $\mathrm{Si} / \mathrm{Al}$ ratio and initial ethylene and propylene yields at $0.5 \mathrm{~h}$ time-on-stream ${ }^{42)}$. The ethylene and propylene yields were strongly dependent on the $\mathrm{Si} / \mathrm{Al}$ ratio, and the maximum propylene yield of about $48 \mathrm{C}-\%$ was obtained at the $\mathrm{Si} / \mathrm{Al}$ ratio of about 15 . On the other hand, the ethylene yield tended to increase with higher $\mathrm{Si} / \mathrm{Al}$ ratio. The product distribution in the zeolitic ethanol conversion process is well known to strongly depend on the acidity as well as the channel structure of the zeolite, and ethanol is considered to first convert to ethylene and then subsequently 
to higher hydrocarbons by oligomerization of ethylene on the acid sites. Cracking of higher hydrocarbons on the acid sites is also considered to generate propylene. Therefore, the observed relationship between the $\mathrm{Si} / \mathrm{Al}$ ratio and the initial ethylene and propylene yields seems to be related to the characteristics of both oligomerization of ethylene and cracking of higher hydrocarbons on the acid sites.

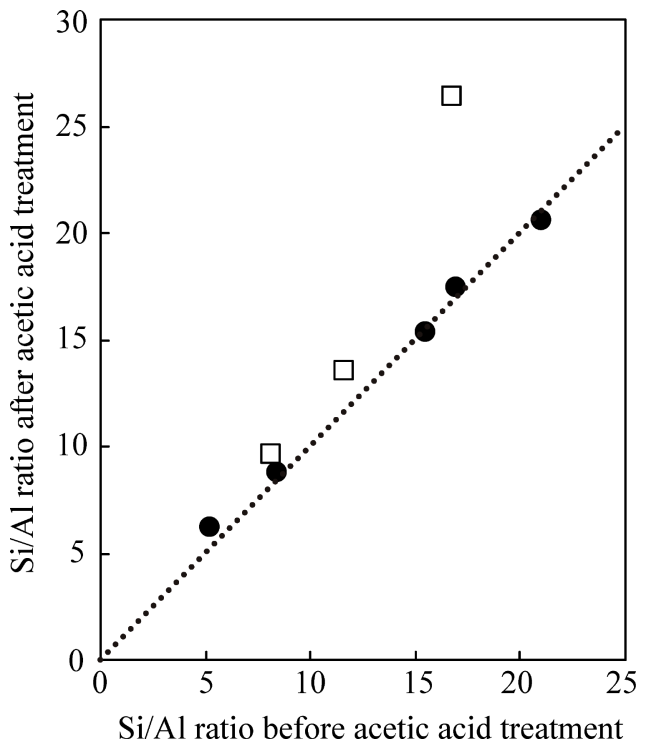

CHA type zeolite synthesized by interzeolite conversion, $(\square)$ SSZ-13.

Fig. 9 Bulk Si/Al Ratios before and after Acetic Acid Treatment

\section{2. Acid Stability}

To ascertain the acid-resistance of high-silica CHA type zeolites, the CHA type zeolite samples were treated with a 90 vol\% acetic acid aqueous solution at $75{ }^{\circ} \mathrm{C}$ for 5 days. Figure 9 shows the relationship between the $\mathrm{Si} / \mathrm{Al}$ ratios prior to and subsequent to the acetic acid treatment ${ }^{43)}$. No differences were observed between these $\mathrm{Si} / \mathrm{Al}$ ratios for $\mathrm{CHA}$ type zeolites synthesized by the interzeolite conversion method. Conversely, notable differences were observed in the SSZ-13 zeolite synthesized with TMAda ${ }^{+}$, particularly the SSZ-13 with a Si/Al ratio of 17 . Specifically, the acid treatment enhanced dealumination of the SSZ-13. These results indicate that the high-silica $\mathrm{CHA}$ type zeolite synthesized by hydrothermal conversion of FAU type zeolite has superior composition stability compared to the SSZ-13 zeolite. The high acid stability of the high-silica CHA type zeolites synthesized by the interzeolite conversion method was further confirmed by treatment with several mineral acid solutions, including $5 \mathrm{M} \mathrm{HCl}_{2} \mathrm{H}_{2} \mathrm{SO}_{4}, \mathrm{HNO}_{3}$, and $\mathrm{H}_{3} \mathrm{PO}_{4}$.

Our previous study found that the dealumination rate of MFI type zeolite with a large number of silanol groups (structure defects) is larger than that of zeolite with small defects ${ }^{53)}$, and results in structural collapse. To clarify the effect of structure defects on the acid stability, the chemical states of the silicon in the CHA type zeolites synthesized by interzeolite conversion and in SSZ-13 were investigated by ${ }^{29} \mathrm{Si}$ MAS NMR with and without ${ }^{1} \mathrm{H}^{-29} \mathrm{Si}$ cross polarization $(\mathrm{CP})$. Figure 10 shows the ${ }^{29} \mathrm{Si}$ MAS NMR spectra of CHA type zeolite and SSZ-13 ${ }^{43)}$. Three peaks were observed centered at
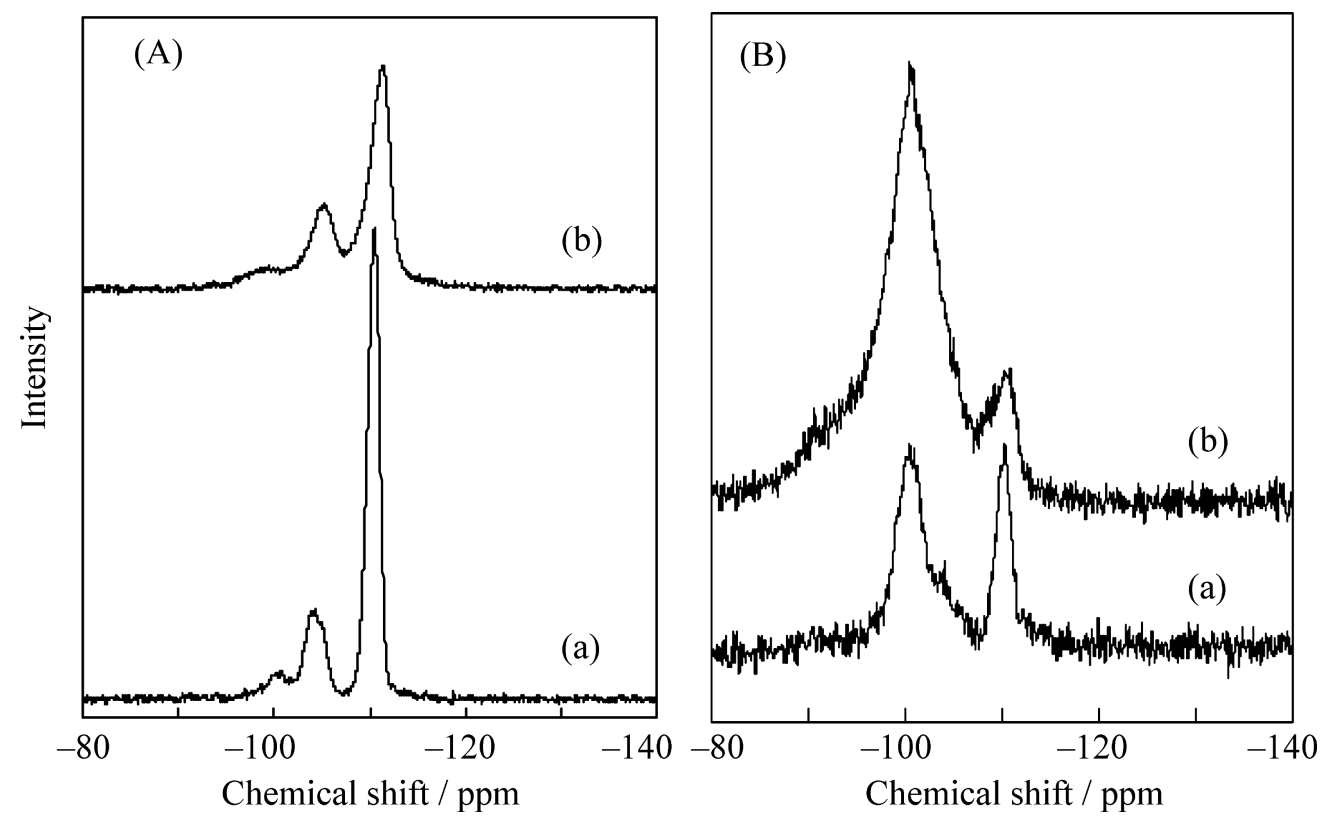

Fig. $10 \quad{ }^{29}$ Si MAS NMR Spectra Measured (A) without and (B) with CP for (a) CHA Type Zeolite Synthesized by Interzeolite Conversion and (b) SSZ-13 
about $-110,-105$, and $-100 \mathrm{ppm}$, which were assigned to $\mathrm{Q}^{4}(0 \mathrm{Al}), \mathrm{Q}^{4}(1 \mathrm{Al})$, and $\mathrm{Q}^{4}(2 \mathrm{Al})+\mathrm{Q}^{3}(0 \mathrm{Al})$, respectively. The peak intensity at about $-100 \mathrm{ppm}$ was enhanced in the CP spectrum. This enhancement was greater for SSZ-13 than for CHA type zeolite, strongly indicating a large number of connectivity defects in the zeolite framework of SSZ-13, resulting in lower acid stability.

\section{3. Membrane for Dehydration of Acetic Acid Aqueous Solution}

CHA type zeolite membrane was prepared on porous $\alpha$-alumina tube using secondary growth techniques, consisting of deposition of CHA seed crystals obtained by the interzeolite conversion method on the support followed by crystal growth under the interzeolite conversion condition in the presence of FAU type zeolite and BTMAOH. The membrane surface was covered with small crystals of size less than $1 \mu \mathrm{m}$. The thickness of the membranes was about $2 \mu \mathrm{m}$. The surface $\mathrm{Si} / \mathrm{Al}$ ratio determined by EDX was 16-20, indicating the formation of a high-silica CHA type zeolite membrane on the alumina support. The pervaporation performance of the high-silica CHA type zeolite membrane was evaluated by the dehydration of $50 \mathrm{wt} \%$ acetic acid aqueous solution at $75{ }^{\circ} \mathrm{C}^{43)}$. The permeate flux and separation factor, $\alpha\left(\mathrm{H}_{2} \mathrm{O} / \mathrm{CH}_{3} \mathrm{COOH}\right)$, were $7.9 \mathrm{kgm}^{-2} \mathrm{~h}^{-1}$ and about 2500 , respectively, and the membrane performance was identical to that of the commercially available NaA type zeolite membranes used for the dehydration of alcohol solution ${ }^{54)}$. The leak acetic acid concentration was about $0.04 \mathrm{wt} \%$. The membrane performance was the highest among the zeolite membranes developed by several research groups, such as the MFI, MOR, T, and MCM-22 type zeolite membranes previously reported ${ }^{55) \sim 58)}$. No change in the pervaporation performance was observed in either flux or separation factor during the time courses, indicating the high acetic acid stability of the CHA type zeolite membrane.

\section{Insight into the Interzeolite Conversion Process}

\section{1. Identification of Intermediate Phases during FAU- * BEA Interzeolite Conversion}

First, we investigated the hydrothermal conversion process of FAU type zeolite into *BEA type zeolite using TEAOH as the OSDA in the absence of *BEA seed crystals by the XRD technique. As shown in Fig. 11 ${ }^{33)}$, the typical XRD peaks corresponding to FAU type zeolite remarkably disappeared after heating for $2 \mathrm{~h}$, and the peaks corresponding to *BEA type zeolite were initially observed after heating for $24 \mathrm{~h}$. Presumably the FAU type zeolite decomposed and the nucleation of ${ }^{*}$ BEA type zeolite occurred during this period. To follow the microscopic changes during the conversion, the intermediate phases were subjected to several analyses. FTIR spectroscopy can observe the

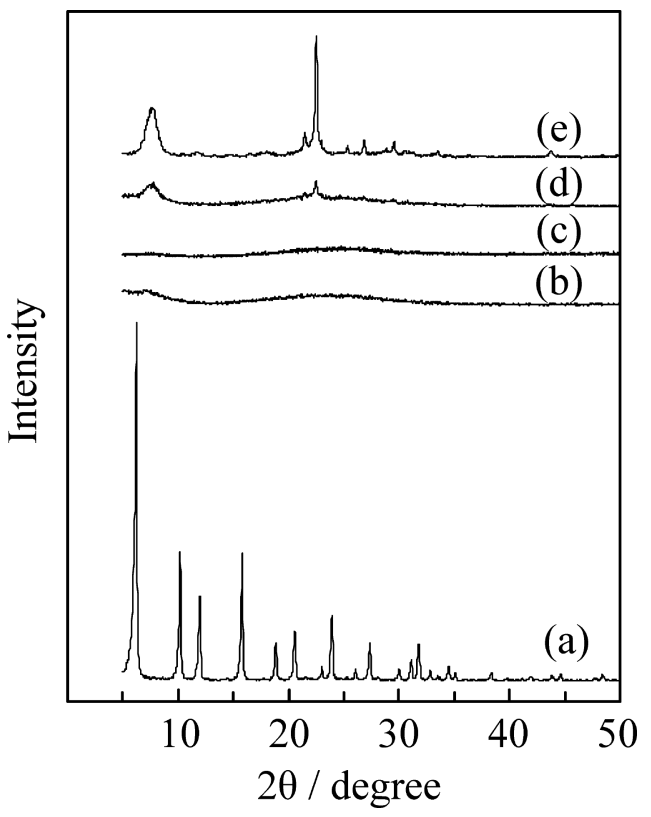

(a) $0 \mathrm{~h}$, (b) $2 \mathrm{~h}$, (c) $18 \mathrm{~h}$, (d) $24 \mathrm{~h}$, and (e) $144 \mathrm{~h}$.

Fig. 11 XRD Patterns of As-made Solid Products Obtained at Different Crystallization Times during Hydrothermal Conversion of FAU Type Zeolite into *BEA Type Zeolite

lattice vibrations of zeolites based on the vibration frequencies in the range between 200 and $1500 \mathrm{~cm}^{-1}$. Figure 12 shows the FTIR spectra of ring vibrations for the phases involved in the conversion process ${ }^{33)}$. As can be seen in Fig. 12(a), sample heated for $0 \mathrm{~h}$ exhibited the typical ring vibrations of FAU type zeolite. Four well-identified sharp peaks at 468, 485, 530, and $613 \mathrm{~cm}^{-1}$ were observed. The peaks at 468 and $485 \mathrm{~cm}^{-1}$ were attributed to the internal $\mathrm{T}-\mathrm{O}^{-} \mathrm{T}$ bending vibrations; and the peaks at 530 and $613 \mathrm{~cm}^{-1}$ were assigned to the external $\mathrm{T}-\mathrm{O}-\mathrm{T}$ bending vibration and double six-membered ring (D6R) vibration, respectively. After 2 and $18 \mathrm{~h}$ heating of FAU, the peaks corresponding to these FAU type zeolite framework vibrations disappeared and only broad peaks were observed (Figs. 12(b) and (c)). Figure 12(d) shows the spectrum of the $24 \mathrm{~h}$ heated sample. Four distinct peaks could be identified. The peak at $474 \mathrm{~cm}^{-1}$ was assigned to the internal $\mathrm{T}-\mathrm{O}-\mathrm{T}$ bending vibration; and the peak at $525 \mathrm{~cm}^{-1}$ was external T-O-T bending vibration. The intensity of the peak at $525 \mathrm{~cm}^{-1}$ became higher, indicating that more crystalline ${ }^{*}$ BEA type zeolite crystals were formed after $24 \mathrm{~h}$ heating. The peak at $575 \mathrm{~cm}^{-1}$ was attributed to the $5 \mathrm{MR}$ vibration. The spectrum of highly crystalline *BEA type zeolite (Fig. 12(e)) exhibited more intense peaks compared to the peaks in Fig. 12(d), indicating a more ordered microscopic arrangement.

Zeolitic subunits can be stabilized through the base hydrolysis of ZSM-5 in the presence of cetyltrimethyl- 


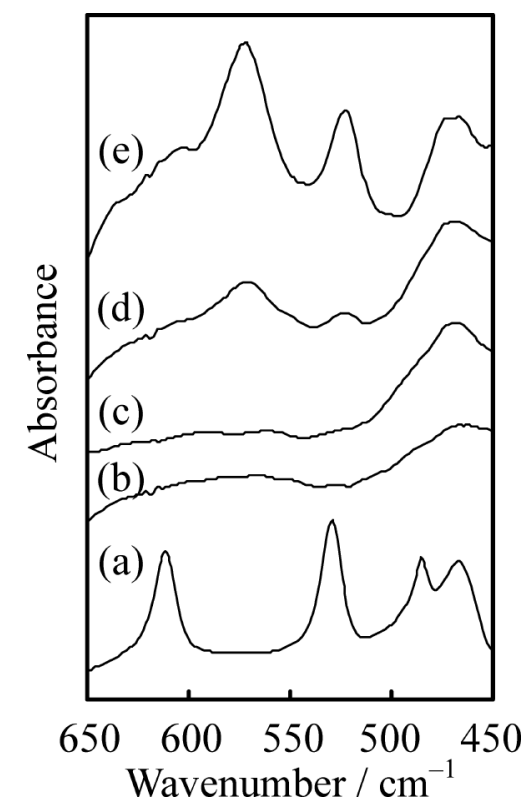

(a) $0 \mathrm{~h}$, (b) $2 \mathrm{~h}$, (c) $18 \mathrm{~h}$, (d) $24 \mathrm{~h}$, and (e) $144 \mathrm{~h}$.

Fig. 12 FTIR Spectra in the Rings Vibration Region of As-made Solid Products Obtained at Different Crystallization Times during Hydrothermal Conversion of FAU Type Zeolite into *BEA Type Zeolite

ammonium $\left(\mathrm{CTA}^{+}\right)$cations $^{59)}$. This finding strongly suggests that $\mathrm{CTA}^{+}$cations have a functionality to stabilize zeolitic precursors, seeds and/or fragments besides the main functionality as a supermolecular template. Therefore, locally ordered aluminosilicate species could be preserved during the hydrothermal conversion of zeolite in mesoporous materials prepared with $\mathrm{CTA}^{+}$cations. Further investigation of the properties of mesoporous products is likely to provide useful information that may explain the mechanism of hydrothermal conversion of zeolite.

The preparation of mesoporous materials from the intermediate phases present during hydrothermal conversion of FAU type zeolite into * BEA type zeolite was carried out. The intermediate phases were obtained at different times of hydrothermal conversion of FAU in the presence of TEAOH. Cetyltrimethylammonium bromide solution was added to the intermediate phases, followed by additional hydrothermal treatment at $150{ }^{\circ} \mathrm{C}$ for 5 days. Hydroxyl groups in the mesoporous products were studied based on the FTIR spectra of $\mathrm{OH}$ groups stretching vibration region $\left(\right.$ Fig. 13) ${ }^{33)}$. In the mesoporous sample obtained after $2 \mathrm{~h}$ heating of FAU (Fig. 13(A)(a)), a strong peak assigned to the isolated terminal silanol groups was observed at $3747 \mathrm{~cm}^{-1}$. In the mesoporous sample obtained after $24 \mathrm{~h}$ heating of FAU, a strong peak at $3610 \mathrm{~cm}^{-1}$ attributed to the acidic bridging $\mathrm{OH}$ groups of $\mathrm{Si}(\mathrm{OH}) \mathrm{Al}$ was observed, associated with the *BEA type zeolite peak

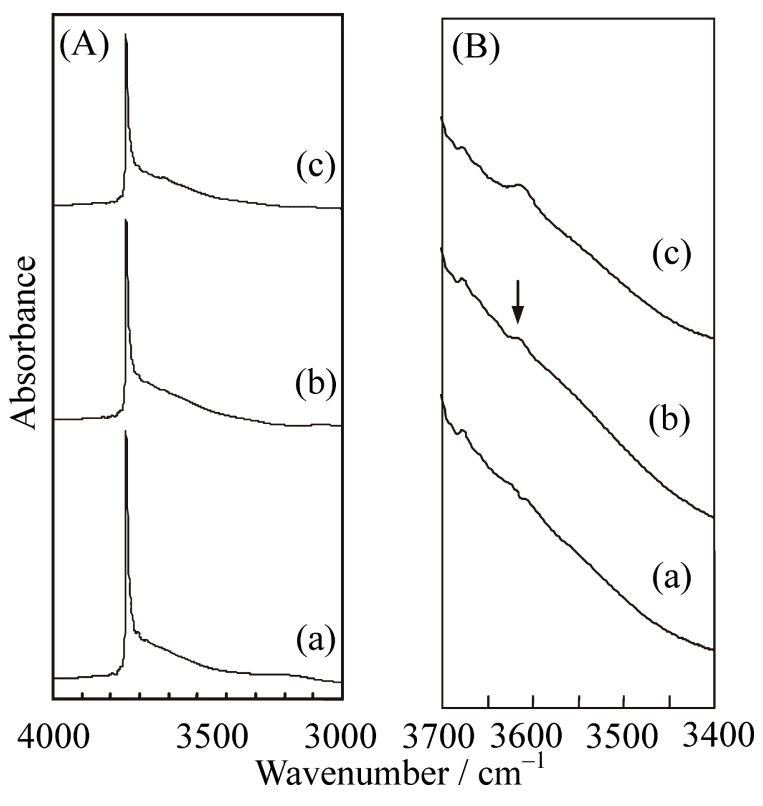

(a) $2 \mathrm{~h}$, (b) $18 \mathrm{~h}$, and (c) $24 \mathrm{~h}$.

Fig. 13 FTIR Spectra in the OH Stretching Region (A) and Magnified Spectra (B) for Calcined Mesoporous Products Prepared from Intermediate Phases Obtained at Crystallization Times

was observed by XRD (Fig. 13(B)(c)). Surprisingly, in the case of the mesoporous sample obtained after $18 \mathrm{~h}$ heating of FAU, a weak band attributed to the acidic bridging $\mathrm{OH}$ groups of $\mathrm{Si}(\mathrm{OH}) \mathrm{Al}$ was also observed, although no *BEA type zeolite peak was observed by XRD (Fig. 11(c)). To our knowledge, such evidence for the presence of acidic bridging $\mathrm{OH}$ groups of $\mathrm{Si}(\mathrm{OH}) \mathrm{Al}$ within mesoporous aluminosilicates has not been reported elsewhere.

The peak at $3610 \mathrm{~cm}^{-1}$ completely disappeared after pyridine adsorption; indicating that strong acidic bridging $\mathrm{OH}$ groups are present in the intermediate phase after $18 \mathrm{~h}$ heating of FAU and then interact with pyridine molecules. The presence of acidic bridging $\mathrm{OH}$ groups indirectly provides adequate evidence for the presence of locally ordered aluminosilicate species, which are sufficient to develop zeolitic Brönsted acid sites in the amorphous intermediate phase obtained after $18 \mathrm{~h}$ heating of FAU. All these results suggest that during FAU- ${ }^{*}$ BEA interzeolite conversion in the presence of TEAOH, FAU type zeolite crystals undergo decomposition into small and locally ordered aluminosilicate species.

\section{2. Analysis of Liquid Phase during Interzeolite Conversion}

Many reports have investigated the crystallization process of zeolite by several techniques such as XRD, NMR, and TEM. Electrospray ionization mass spectroscopy (ESI-MS) also has great potential for the analysis of structures of oligomeric aluminosilicate species 


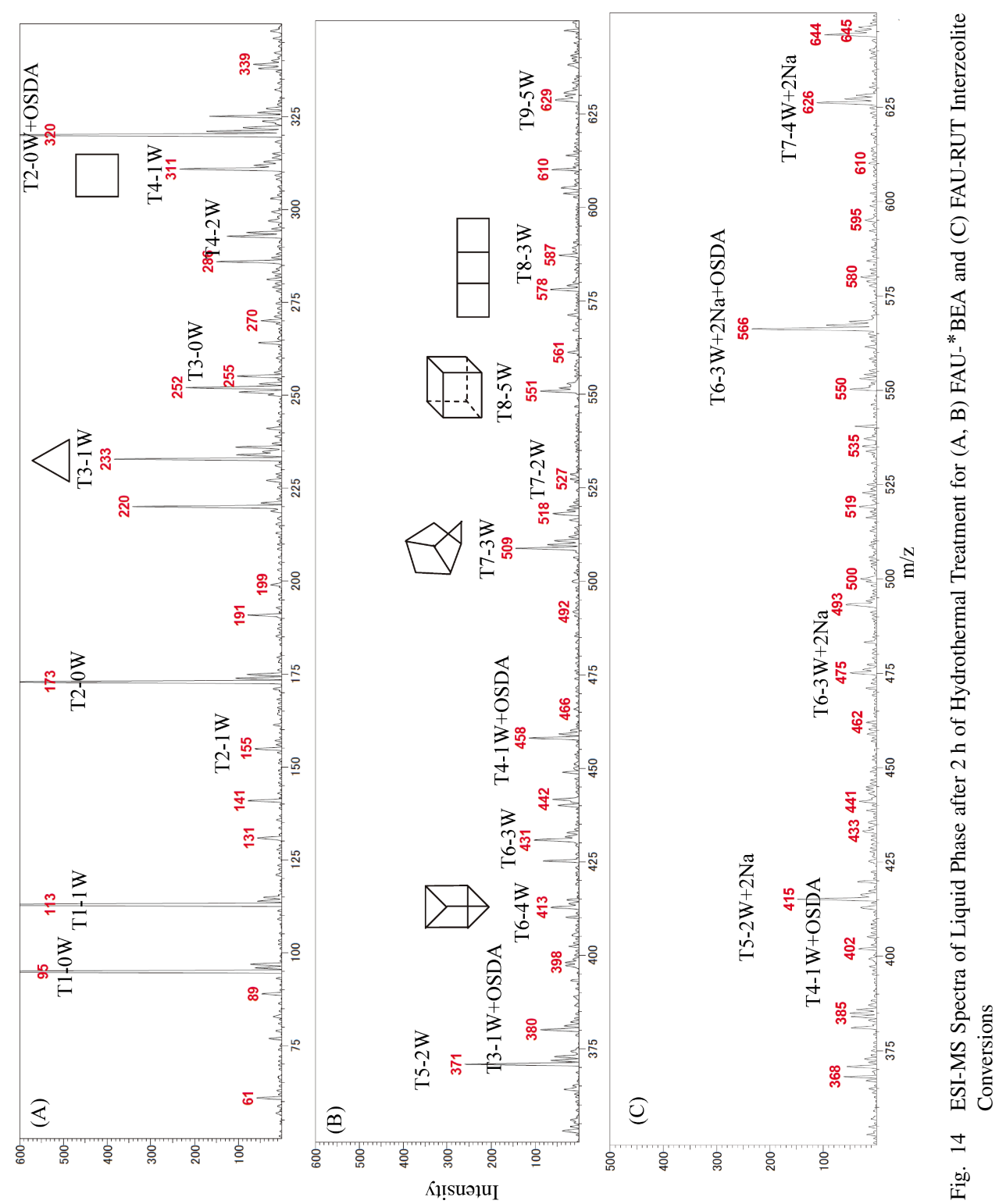

present in the liquid phase during crystallization ${ }^{60) \sim 62)}$. Therefore, we applied this technique to get a better understanding of interzeolite conversion process. ESIMS spectra of aqueous solutions obtained at the initial stage of FAU-*BEA (TEAOH) and FAU-RUT (TMAOH) interzeolite conversions are shown in Fig. 14. All negative-ion ESI-MS spectra detected two types of chemical species with various mass to charge ratios $(\mathrm{m} / \mathrm{z})$, clustered with and without cations $\left(\mathrm{TMA}^{+}, \mathrm{TEA}^{+}\right.$or $\left.\mathrm{Na}^{+}\right)$. The chemical species detected was designated on the ESI-MS spectrum as TX$Y \mathrm{~W}$. "T" and "W" denote $\mathrm{T}$ atoms ( $\mathrm{Si}$ or $\mathrm{Al}$ ) and $\mathrm{H}_{2} \mathrm{O}$, respectively. " $X$ " and " $Y$ " denote the $\mathrm{T}$ atom number and number of dehydration-condensations between chemical species, respectively. For example: $Y=1$, $2 \mathrm{Si}(\mathrm{OH})_{4} \rightarrow(\mathrm{HO})_{3} \mathrm{Si}-\mathrm{O}-\mathrm{Si}(\mathrm{OH})_{3}+\mathrm{H}_{2} \mathrm{O}$. Chemical structures speculated from their $\mathrm{m} / \mathrm{z}$ values are also designated above peaks. Similar chemical species were observed in both of ESI-MS spectra in the $\mathrm{m} / \mathrm{z}$ range of 50-350. However, a large difference was observed in the $m / z$ range of $350-650$. For FAU- ${ }^{*}$ BEA interzeolite conversion, most chemical species observed were assigned to "TX-YW" without cations. On the other hand, for FAU-RUT interzeolite conversion, chemical species with cations "T $X-Y \mathrm{~W}+$ cation" were observed, suggesting the presence of aluminosilicate species with higher aluminum content.

Interestingly, T6-4W, T8-3W, and T8-5W species were detected only in the ESI-MS spectrum of FAU*BEA interzeolite conversion in the presence of TEAOH. As can be seen in Fig. 14(B), these species consist of four-membered ring (4 MR) chains. Investigation of the crystallization mechanism of *BEA type zeolite using high energy X-ray diffraction measurements found that pseudo- *BEA structure is formed by connecting $4 \mathrm{MR}$ structures such as double three-membered rings 
Table 5 Mass Numbers of Aluminosilicates in Chemical Species Clustered with Cations in Liquid Phase Detected by ESI-MS after $2 \mathrm{~h}$ of Hydrothermal Conversion of (gray) FAU Type Zeolite and (bold) Amorphous Gel in the Presence of TEAOH

\begin{tabular}{|c|c|c|c|c|c|c|c|c|c|}
\hline & $-0 \mathrm{~W}$ & $-1 \mathrm{~W}$ & $-2 \mathrm{~W}$ & $-3 \mathrm{~W}$ & $-4 \mathrm{~W}$ & $-5 \mathrm{~W}$ & $-6 \mathrm{~W}$ & $-7 \mathrm{~W}$ & $-8 \mathrm{~W}$ \\
\hline T-1 & 95 & & & & & & & & \\
\hline $\mathrm{T}-2$ & 173 & & & & & & & & \\
\hline $\mathrm{T}-3$ & 251 & 233 & & & & & & & \\
\hline $\mathrm{T}-4$ & & 311 & 293 & & & & & & \\
\hline T-5 & & & 371 & & & & & & \\
\hline T-6 & & & & 431 & & & & & \\
\hline T-7 & & & & & & & & & \\
\hline $\mathrm{T}-8$ & & & & & & 551 & & & \\
\hline T-9 & & & & & & 629 & & & \\
\hline T-10 & & & & & & & 689 & & \\
\hline T-11 & & & & & & & & & \\
\hline $\mathrm{T}-12$ & & & & & & & & 827 & \\
\hline $\mathrm{T}-13$ & & & & & & & & & \\
\hline
\end{tabular}

$\mathrm{T}-X$ denotes aluminosilicate species with the $\mathrm{T}$ atom number of $X$ and $Y$ in $-Y \mathrm{~W}$ denotes the number of dehydration-condensations.

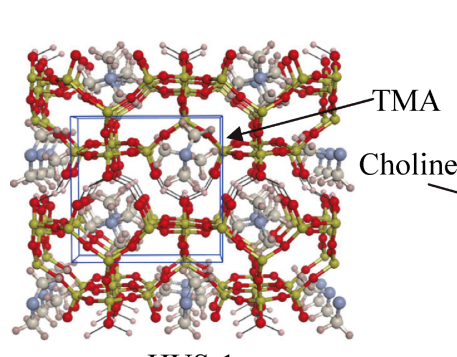

HUS-1

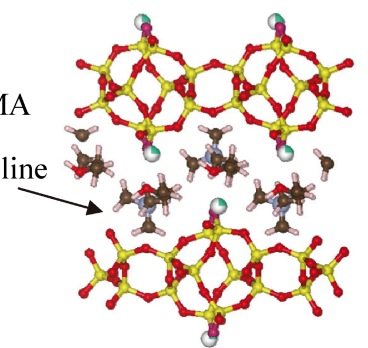

HUS-2
Fig. 15 Crystal Structure Models of HUS-1 and HUS-2 Determined by Rietveld Analysis along the [001] and [100] Directions, Respectively

and 4-2 secondary building units ${ }^{63)}$. The 4 MR chain structure is consistent with that of the chemical species detected by ESI-MS.

Mass numbers of aluminosilicates in chemical species clustered with cations in liquid phase after $2 \mathrm{~h}$ of hydrothermal conversion of FAU type zeolite and amorphous materials are listed in Table 5. Clearly the aluminosilicate species detected are distributed diagonally, which implies that the dehydration-condensation reaction between aluminosilicate species occurs during the interzeolite conversion process. Aluminosilicate species with larger $m / z$ values were detected in the ESIMS spectrum of FAU-*BEA interzeolite conversion as compared to the synthesis of *BEA type zeolite from amorphous materials. Detection of aluminosilicate species with larger $m / z$ values as nanoparts seems to support the fast crystallization rate for interzeolite conversion.

\section{Conclusions}

We succeeded in synthesizing many types of zeolites by interzeolite conversion of several types of zeolites, and found that the structural similarity between the starting zeolite and the final crystallized zeolite is the crucial factor for interzeolite conversion. Our finding confirmed that the interzeolite conversion route is an attractive strategy for zeolite synthesis. However, to establish the interzeolite conversion route as an alternative zeolite synthesis method, we must further characterize the chemical structures of nanoparts generated from the starting zeolite.

Layered silicates are also important for zeolite synthesis ${ }^{64)}$. The silanol groups on the interlayer surfaces of layered silicates are condensed between the layers, and the layered structures are transformed into zeolitelike 3-D structures, a process that is called topotactic conversion. If the crystal structures of the nanosheets of layered silicates can be determined, we can easily predict the framework structures of zeolites that are obtained by topotactic conversion via interlayer dehydration-condensation. Therefore, we are also interested in the synthesis of novel layered silicates with unique crystal structures. Very recently, we succeeded in synthesizing two new layered silicates, HUS-1 (Hiroshima University Silicate-1) and HUS-2 as shown in Fig. 15 ${ }^{65), 66)}$, and zeolitization is now in progress.

\section{References}

1) International Zeolite Association Web site: http://www.iza-online.org/.

2) Shiralkar, V. P., Clearfield, A., Zeolites, 9, 363 (1989). 
3) Ren, N., Yang, Z.-J., Lv, X.-C., Shi, J., Zhang, Y.-H., Tang, Y., Micropor. Mesopor. Mater., 131, 103 (2010).

4) Song, J., Dai, L., Ji, Y., Xiao, F.-S., Chem. Mater., 18, 2775 (2006).

5) Wu, Z., Song, J., Ren, L., Ji, Y., Li, J., Xiao, F.-S., Chem. Mater, 20, 357 (2008).

6) Xie, B., Song, J., Ren, L., Ji, Y., Li, J., Xiao, F.-S., Chem. Mater, 20, 4533 (2008).

7) Majano, G., Delmotte, L., Valtchev, V., Mintova, S., Chem. Mater, 21, 4184 (2009).

8) Kamimura, Y., Chaikitlisilp, W., Itabashi, K., Shimojima, A., Okubo, T., Chem. Asian, 5, 182 (2010).

9) Yokoi, T., Yoshioka, M., Imai, H., Tatsumi, T., Angew. Chem., Int. Ed., 48, 9884 (2009).

10) Iyoki, K., Kamimura, Y., Itabashi, K., Shimojima, A., Okubo, T., Chem. Lett., 39, 730 (2010).

11) Ng, E.-P., Chateigner, D., Bein, T., Valtchev, V., Mintova, S., Science, 335, 70 (2012).

12) Barrer, R. M., J. Chem. Soc., 127 (1948).

13) Barrer, R. M., Hinds, L., White, E. A., J. Chem. Soc., 1466 (1953).

14) Barrer, R. M., Marcilly, C., J. Chem. Soc. A, 2735 (1970).

15) Perrotta, A. J., Kibby, C., Mitchell, B. R., Tucci, E. R., J. Catal., 55, 240 (1978).

16) Dwyer, F. G., Chu, P., J. Catal., 59, 263 (1979).

17) Subotić, B., Škrtić, D., Šmit, I., Sekanović, L., J. Cryst. Growth, 50, 498 (1980).

18) Subotić, B., Šmit, I., Madžija, O., Sekanović, L., Zeolites, 2 , 135 (1982).

19) Subotić, B., Sekanović, L., J. Cryst. Growth, 75, 561 (1986).

20) Zones, S. I., van Nordstrand, R. A., Zeolites, 8, 166 (1988).

21) Zones, S. I., van Nordstrand, R. A., Zeolites, 8, 409 (1988).

22) Zones, S. I., J. Chem. Soc., Faraday Trans., 87, 3709 (1991).

23) Zones, S. I. Nakagawa, Y., Micropor. Mater, 2, 557 (1994).

24) Khodabandeh, S., Davis, M. E., Micropor. Mater., 9, 149 (1997).

25) Khodabandeh, S., Lee, G., Davis, M. E., Micropor. Mater., 11, 87 (1997).

26) Norby, P., J. Am. Chem. Soc., 119, 5215 (1997).

27) Kubota, Y., Tawada, S., Nakagawa, K., Naitoh, C., Sugimoto, N., Fukushima, Y., Hanaoka, T., Imada, Y., Sugi, Y., Micropor. Mesopor: Mater., 37, 291 (2000).

28) Ahedi, R. K., Kubota, Y., Sugi, Y., J. Mater. Chem., 11, 2922 (2001).

29) Kubota, Y., Maekawa, H., Miyata, S., Tatsumi, T., Sugi, Y., Micropor. Mesopor. Mater., 101, 115 (2007).

30) Jon, H., Nakahata, K., Lu, B., Oumi, Y., Sano, T., Micropor. Mesopor. Mater., 96, 72 (2006).

31) Jon, H., Takahashi, S., Sasaki, H., Oumi, Y., Sano, T., Micropor. Mesopor. Mater, 113, 56 (2008).

32) Itakura, M., Inoue, Y., Takahashi, A., Fujitani, T., Oumi, Y., Sano, T., Chem. Lett., 37, 908 (2008).

33) Jon, H., Ikawa, N., Oumi, Y., Sano, T., Chem. Mater, 20, 4135 (2008).

34) Inoue, T., Itakura, M., Jon, H., Oumi, Y., Takahashi, A., Fujitani, T., Sano, T., Micropor. Mesopor. Mater, 122, 149 (2009).

35) Sasaki, H., Jon, H., Itakura, M., Inoue, T., Ikeda, T., Oumi, Y., Sano, T., J. Porous Mater, 16, 465 (2009).
36) Itakura, M., Oumi, Y., Sadakane, M., Sano, T., Mater. Res. Bull., 45, 646 (2010).

37) Shibata, S., Itakura, M., Ide, Y., Sadakane, M., Sano, T., Micropor. Mesopor. Mater, 138, 32 (2011).

38) Honda, K., Yashiki, A., Itakura, M., Ide, Y., Sadakane, M., Sano, T., Micropor. Mesopor. Mater., 142, 161 (2011).

39) Yashiki, A., Honda, K., Fujimoto, A., Shibata, S., Ide, Y., Sadakane, M., Sano, T., J. Cryst. Growth., 325, 96 (2011).

40) Sano, T., Catalysts \& Catalysis, 53, 392 (2011).

41) Itakura, M., Ota, K., Shibata, S., Inoue, T., Ide, Y., Sadakane, M., Sano, T., J. Cryst. Growth, 314, 274 (2011).

42) Goto, I., Itakura, M., Shibata, S., Ide, Y., Sadakane, M., Sano, T., Micropor. Mesopor. Mater, 158, 117 (2012).

43) Yamanaka, N., Itakura, M., Kiyozumi, Y., Ide, Y., Sadakane, M., Sano, T., Micropor. Mesopor. Mater., 158, 141 (2012).

44) Honda, K., Itakura, M., Matsuura, Y., Onda, A., Ide, Y., Sadakane, M., Sano, T., J. Nanosci. Nanotechnol., 13, 3020 (2013).

45) Kerr, G. T., J. Phys. Chem., 72, 1385 (1968).

46) Warzywoda, J., Thompson, R. W., Zeolites, 11, 577 (1991).

47) Lu, B., Tsuda, T., Oumi, Y., Itabashi, K., Sano, T., Micropor. Mesopor. Mater., 76, 1 (2004).

48) Cundy, C. S., Cox, P. A., Micropor. Mesopor. Mater., 82, 1 (2005).

49) Itabashi, K., Kamimura, Y., Iyoki, K., Shimojima, A., Okubo, T., J. Am. Chem. Soc., 134, 11542 (2012).

50) Jacobsen, C. J., Madsen, C., Houzvicka, J., Schmidt, I., Carlsson, A., J. Am. Chem. Soc., 122, 7116 (2000).

51) Choi, M., Cho, H. S., Srivastava, R., Venkatesan, C., Choi, D.H., Ryoo, R., Nat. Mater., 5, 718 (2006).

52) Ogura, M., Shinomiya, S., Tateno, J., Nara, Y., Kikuchi, E., Matsukata, M., Chem. Lett., 882 (2000).

53) Sano, T., Ikeya, H., Kasuno, T., Wang, Z. B., Kawakami, Y., Soga, K., Zeolites, 19, 80 (1997).

54) Sato, K., Sugimoto, K., Nakane, T., J. Membr. Sci., 307, 181 (2008).

55) Li, G., Kikuchi, E., Matsukata, M., J. Membr. Sci., 218, 185 (2003).

56) Cui, Y., Kita, H., Okamoto, K., J. Membr. Sci., 236, 17 (2004).

57) Sato, K., Sugimoto, K., Kyotani, T., Shimotsuma, N., Kurata, T., J. Membr. Sci., 385, 20 (2011).

58) Makita, K., Hirota, Y., Egashira, Y., Yoshida, K., Sasaki, Y., Nishiyama, N., J. Membr. Sci., 372, 269 (2011).

59) Wang, H., Liu, Y., Pinnavaia, T. J., J. Phys. Chem. B, 110, 4524 (2006).

60) Bussian, P., Sobott, F., Brutschy, B., Schrader, W., Schüth, F., Angew. Chem., Int. Ed., 39, 3901 (2000).

61) Pelster, S. A., Schrader, W., Schüth, F., J. Am. Chem. Soc., 128, 4310 (2006).

62) Lim, I. H., Schrader, W., Schüth, F., Micropor. Mesopor. Mater., 166, 20 (2013).

63) Inagaki, S., Nakatsuyama, K., Saka, Y., Kikuchi, E., Kohara, S., Matsukata, M., J. Phys. Chem. C, 111, 10285 (2007).

64) Marler, B., Gies, H., Eur. J. Mineral., 24, 405 (2012).

65) Ikeda, T., Oumi, Y., Honda, K., Sano, T., Izumi, F., Momma, K., Inorg. Chem., 50, 2294 (2011).

66) Tsunoji, N., Ikeda, T., Ide, Y., Sadakane, M., Sano, T., J. Mater. Chem., 22, 13682 (2012). 
要旨

\section{ゼオライト合成におけるゼオライト転換法の可能性}

佐野 庸治，板倉 正也，定金 正洋

広島大学大学院工学研究科応用化学専攻, 739-8527 広島県東広島市鏡山1-4-1

\begin{abstract}
ゼオライトを出発原料に用いたゼオライト合成, ゼオライト 転換により, FAU, ベータ（以下，*BEA）およびLEV型ゼオ ライトから*BEA, CHA, LEV, RUT および MFI等の様々な ゼオライト合成に成功した。アモルファスゲルを原料に用いる 通常のゼオライト合成と比べ, これらのゼオライトを出発原料 に用いた場合には結晶化速度が増大した。この結晶化速度の増 大は, 出発ゼオライトの分解により生成した局所的秩序構造を 有するアルミノシリケート種である構造ユニット(ナノパーツ)
\end{abstract}

\begin{abstract}
が他のゼオライトへ再構築されていることを強く示唆してい る。したがって, 出発ゼオライトと最終生成物であるゼオライ 卜間の構造類似性がゼオライト転換を決める極めて重要な因子 である。これらの結果は, 新たなゼオライト合成ルートとして のゼオライト転換法の可能性を示すものであり, 構造の異なる ナノパーツを化学的操作により組み立てていく手法が確立され れば，新規構造を有するゼオライトを自由自在に設計すること も近い将来可能になると期待している。
\end{abstract}

